\title{
BMJ Open Pilot study on identification of incidents in healthcare transitions and concordance between medical records and patient interview data
}

\author{
Marije A van Melle, ${ }^{1,2}$ Daphne C A Erkelens, ${ }^{1}$ Henk F van Stel, ${ }^{1}$ Niek J de Wit, ${ }^{1}$ \\ Dorien L M Zwart ${ }^{1}$
}

To cite: van Melle MA, Erkelens DCA, van Stel HF, et al. Pilot study on identification of incidents in healthcare transitions and concordance between medical records and patient interview data. BMJ Open 2016:6:e011368. doi:10.1136/bmjopen-2016011368

- Prepublication history for this paper is available online. To view these files please visit the journal online (http://dx.doi.org/10.1136/ bmjopen-2016-011368).

Received 1 February 2016 Revised 2 May 2016 Accepted 8 June 2016

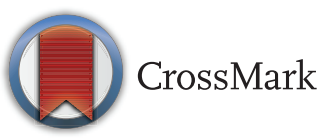

${ }^{1}$ Department of General Practice, Julius Center for Health Sciences and Primary Care, University Medical Center Utrecht, Utrecht, The Netherlands

2Julius Center, UMC Utrecht, Utrecht, The Netherlands

\section{Correspondence to} Marije A van Melle; m.a.vanmelle-2@umcutrecht. $\mathrm{nl}$

\section{ABSTRACT}

Objective: To investigate whether transitional incidents can be identified from the medical records of the general practitioners and the hospital and to assess the concordance of transitional incidents between medical records and patient interviews.

Design: A pilot study.

Setting: The study was conducted in 2 regions in the Netherlands: a rural and an urban region.

Participants: A purposeful sample of patients who experienced a transitional incident or are at high risk of experiencing transitional incidents.

Main outcome measures: Transitional incidents were identified from both the interviews with patients and medical records and concordance was assessed. We also classified the transitional incidents according to type, severity, estimated cause and preventability.

Results: We identified 28 transitional incidents within 78 transitions of which 3 could not be found in the medical records and another 5 could have been missed without the patient as information source. To summarise, $8(29 \%)$ incidents could have been missed using solely medical records, and $7(25 \%)$ using the patients' information exclusively. Concordance in transitional incidents between patient interviews and medical records was $64 \%(18 / 28)$. The majority of the transitional incidents were unsafe situations; however, $43 \%(12 / 28)$ of the incidents reached the patient and $18 \%(5 / 28)$ caused temporary patient harm. Over half of the incidents were potentially preventable.

Conclusions: This pilot study suggests that the majority of transitional incidents can be identified from medical records of the general practitioner and hospital. With this information, we aim to develop a measurement tool for transitional incidents in the medical record of general practitioner and hospital.

\section{INTRODUCTION}

In the Netherlands, the general practitioner has a central role in the patients' journey. The general practitioner is the first point of contact, provides basic healthcare and is

\section{Strengths and limitations of this study}

- To the best of our knowledge, this is the first study in which patient interviews were compared with medical records to investigate transitional patient safety and the incidence of transitional incidents.

- This pilot study encompasses the entire transitional care process as it includes all patient transitions between general practitioner and hospital.

- Since this study is a pilot study, the small sample size and the purposeful recruitment method do not permit generalising the results.

- The models used for classification of the transitional incidents are not developed and validated for transitional care, for which no validated models yet exist.

- Starting analysis with the patient interviews could have created hindsight bias as the researcher was not blinded for this patient information when identifying transitional incidents from the medical records.

gatekeeper to the specialist healthcare services in hospitals. Transitions between the general practitioner (GP) and hospital include referral of patients from GP to hospital, discharge after hospital admission and concurrent care by a general practitioner and specialist at the outpatient clinic. During these transitions, the primary interest is the establishment of a continuous, high quality, integrated care process in which patients' safety is guaranteed. ${ }^{12}$

During the patients' journey through the different levels of the healthcare system, patient safety incidents tend to accumulate. ${ }^{3}$ It is important to identify these transitional incidents (TIs) and assess them adequately, to better understand the risks and improve patient safety during transitions in healthcare. A medical record review study is a tool for the assessment of patient safety and harm. 
Since the 90s, several large international medical record review studies have been conducted. ${ }^{4-10}$ Initially, patient safety studies focused on hospitals, but recently record studies on incidents have also been performed in primary care settings. ${ }^{11}$ However, medical record review of the patient journey between these levels of healthcare is yet to be explored.

For an adequate overview of the complete patient journey, the patient's story may render additional information. Studies on continuity of care hypothesise that patients are able to identify adverse events affecting their care. ${ }^{12}$ Given the fact that the patient is the only continuous factor in all healthcare transitions, involving the patients' experience may even be an alternative route for adequate identification of TIs. With this pilot study, we aimed to investigate whether TIs can be identified from the medical records of the general practitioners and the hospital and to assess the concordance between these medical records and the patient interviews. With this information, we intend to develop a measurement tool assessing TIs in the medical record of both the GP and the hospital.

\section{METHODS}

\section{Design and setting}

We conducted a pilot study comparing the TIs identified from medical records of the GP and the hospital with those identified through patient interviews. Patients were recruited in two regions in the Netherlands: a rural region with one regional hospital and referring primary care practices and an urban region with one university hospital and one smaller city hospital, together with referring primary care practices. In both regions, we concentrated on patients treated in the internal, cardiovascular and gastroenterology departments. The study is part of a larger project on transitional patient safety, namely the Transitional Incident Prevention Programme (TIPP). ${ }^{13}$ According to Dutch law, this study was exempt from formal medical-ethical approval (METC number 13/142, medical ethical committee UMC Utrecht). The final goal of this pilot study is to develop a measurement tool for measuring TIs in the medical records of the GP and the hospital.

\section{Patients}

We used a convenience sampling strategy to recruit participants. Between October 2013 and July 2014, healthcare professionals of all participating hospital departments and affiliated GP practices were asked to recruit patients that experienced a TI or had a high risk of experiencing TIs. We considered comorbidity, polypharmacy, elderly patients and multiple transitions as risk factors for TIs. The healthcare professional gave eligible patients information on the TIPP study and asked whether the patient was willing to participate and whether our research office could contact them. If interested, patients received extra information on the nature of this pilot study by mail and by telephone. After giving consent, our researchers visited the patient at home for an interview. Prior to the interview, patients signed a written informed consent for the use of the interview data and the acquisition and use of their GP and hospital records.

\section{Definitions}

The absence of international consensus about patient safety terms and definitions hinders comparison of studies. ${ }^{14}$ Therefore, it is essential to emphasise the definitions we used in this article. The definitions are presented in table 1.

\section{DATA COLLECTION}

For our study, we used data from three sources: patient interviews, medical records of the GP and the medical records of the hospital. The patient interviews provided information about the incidents patients experienced during their transitions in healthcare. Subsequently, we retrieved their medical records through their GPs and the hospital departments and assessed whether any TIs were present. The data in the different data sources were collected independently and combined in the data collection and analysis.

Table 1 Definitions of patient safety terms used in this manuscript

Transition

Every shift/movement (eg, referral, admission, discharge, consultation at outpatient clinic) patients make between healthcare professionals in primary and secondary care as their condition and care needs change during the course of illness. $^{2}$

Transitional A set of services and environments care designed to ensure the coordination and continuity of healthcare as patients transfer between different levels and locations of care. ${ }^{2}$

Transitional Any unintended or unexpected event in incident patient care between different healthcare organisations which could have led or did lead to harm for one or more patients receiving care. In this report, we chose to focus on transitional incidents between primary care and hospital instead of all levels of care. If an unintentional event occurs in primary care and the results of the incident are noticed in the hospital or vice versa, this also counts as a transitional incident. Adverse event Any injury caused by medical care. ${ }^{15}$ Near miss An act of commission or omission that could have harmed the patient but did not do so as a result of chance, prevention or mitigation. ${ }^{16}$

Unsafe situation Circumstances or events occurred that had the capacity to cause error. ${ }^{17}$ 
We first constructed a chronological timeline of the journey of each individual patient, based on relevant information from the patient interviews. These timelines were used as guidance for the analysis of the medical record data. We also collected the following patient characteristics: age, gender, number of chronic diseases in history and number of currently used medications. Two researchers (MAvM, DCAE) jointly composed the timeline for the first patient. To establish a standard approach to identify and display relevant information from the interviews and the medical records, our researchers then constructed a second and third timeline independently. Disagreements were discussed until consensus was reached. One researcher (DCAE) constructed the timelines for the remainder of patients.

\section{Data analysis}

We counted the number of healthcare transitions per patient, calculated the period in which these transitions took place (in months) and the average number of transitions per patient. The transition period started with the first patient transition (usually from GP to hospital) and stopped at the end of the final transition back to the GP (usually when the diagnostic process or treatment in hospital is completed) or the date of the medical record collection. A transition comprised a referral, a hospital discharge or visit to the outpatient clinic. The visit to the outpatient clinic was only included if an event occurred of which our researchers judged that the GP should be informed (eg, in the case of a new diagnosis, the start of a new treatment, a treatment or policy change or discharge from the outpatient clinic). The source of the information was registered (medical record, patient interview or both). Subsequently, all TIs were identified and classified according to type, cause, severity and preventability. Since this study concerns a pilot study, the methods for identification of TIs are still under development. An existing TI assessment form was not available and our researchers jointly gained the experience of identifying TIs during the process. Again, to establish a standard approach, the first patient was assessed jointly and the second and third patients were assessed independently by our researchers MAvM and DCAE. For every transition made by the patient, the entire transition process was screened for possible TIs, following the definition of TIs in table 1. Our researchers used a previously comprised list with the vulnerable steps in the transition process and risk factors for TIs (eg, accessibility, triage, diagnosis, diagnostic testing, medication/ prescription, communication/collaboration, referral and handoff information, in hospital referrals, the discharge process, self-care advice, after hours' care, multiple treating physicians, care coordinator) to guide the identification process. In this process, we were helped by the patient interview. The identified TIs were subdivided into three types of incidents: unsafe situations, near misses and adverse events (for definitions, see table 1). To classify the cause of the TI, we used the Eindhoven Classification Model, which distinguishes organisation, technique, human acts and patients' actions as possible causal factors. ${ }^{18}$ We did not request additional information from the involved GPs and specialists. Therefore, we could only estimate causal factors. Incidents can be the result of more than one cause, so the total number of causes was higher than the number of incidents. We classified severity of TIs according to the National Coordinating Council for Medication Error Reporting and Prevention Index (NCC MERP Index). ${ }^{17}$ We added the items delay and mental harm to the NCC MERP Index because we considered these items to better fit transitional care. This resulted in the following levels of harm:

A. 'Circumstances or events occurred that had the capacity to cause error',

B. 'Error occurred but did not reach the patient',

C. 'Error occurred that reached the patient but did not cause patient harm',

D. 'Error occurred that reached the patient and required monitoring to preclude harm or confirm that it caused no harm',

E. 'Error occurred that may have contributed to or resulted in temporary (mental or physical) harm or prolonged suffering from curable symptoms and required intervention',

F. 'Error occurred that may have contributed to or resulted in (mental or physical) harm and required an initial or prolonged hospital stay',

G. 'Error occurred that contributed to or resulted in permanent patient harm',

H. 'Error occurred that required intervention to sustain patient's life',

I. 'Error occurred that may have contributed to or resulted in patient death'.

Level A of the NCC MERP fits the definition of an 'unsafe situation', levels B through D pertain to a ' near miss' and levels E through I an 'adverse event'.

We scored preventability on a six-point scale from '(nearly) no evidence for preventability' to '(definitely) evidence for preventability' according to the current level of expected performance for healthcare professionals. A score of 4-6 indicated that the researcher regarded the incident as having a more than $50 \%$ chance of being preventable. This subjective score is often used in medical record review studies. ${ }^{10}$

Finally, data sources of the TIs identified from the medical records and patient interviews were registered. Concordance between data sources of the TIs was determined.

\section{RESULTS}

\section{Patients}

The GPs and specialists of both regions identified 19 eligible patients: 11 by GPs and 8 by specialists. Six of these 19 patients declined participation for the following 
reasons: language barrier $(\mathrm{n}=1)$, too much effort given their age $(n=1)$, worsening of disease $(n=2)$, nothing to report $(n=1)$ and inability to reach the patient $(n=1)$. In total, 13 patients were interviewed and of 12 patients all the medical records could be attained. In one patient, the patient journey included a general practitioner and two hospitals. The medical record of one of these hospitals couldn't be retrieved. The median age of the participants was 59 years and 7/13 (54\%) were female (table 2).

\section{Transitional incidents}

In total, the 13 patients made 78 transitions between the GP and the hospital with a median of 6 transitions per patient. The median period in which the patients transitioned was 6 months (range 1.5 weeks to 18 months). During these 78 transitions, the participating patients experienced 28 TIs. An illustration of the process of identifying and classifying incidents from our timelines is displayed in table 3. Table 4 shows a summary of our analysis of TIs for all patients.

Besides TIs between the GP and the hospital, we also encountered incidents between two different hospitals and between the GP and the community pharmacy. We did not include these incidents because they did not meet the focus of our study, namely transitional care between the GP and the hospital. However, it is likely that these incidents also enclose an opportunity for improving overall transitional patient safety.

\section{Type and severity}

The majority of TIs were classified as an unsafe situation (16/28=57\%; NCC MERP category A). Of the other 12 TIs, 7 were classified as near misses $(7 / 28=25 \%$; 4 were classified as level $\mathrm{C}$ and 3 as level $\mathrm{D}$ ). The remaining five TIs were classified as adverse events and resulted in

\begin{tabular}{|c|c|c|}
\hline & n (\%) & $\begin{array}{l}\text { median } \\
\text { (IQR) }\end{array}$ \\
\hline Age (years)* & 59 & 28 \\
\hline Gender (\% male) & 6 & 46 \\
\hline Participating region (\% urban) & 8 & 62 \\
\hline Number of transitions per patient ${ }^{*}$ & 6 & 6.5 \\
\hline Period of transitions (months) ${ }^{\star}$ & 6 & 5.75 \\
\hline \multicolumn{3}{|c|}{ Number of chronic diseases $†$ in history $\ddagger$} \\
\hline$\leq 1$ & 6 & 46 \\
\hline$\overline{2}-4$ & 6 & 46 \\
\hline$\geq 5$ & 1 & 8 \\
\hline \multicolumn{3}{|c|}{ Number of medications used by the patient } \\
\hline$\leq 1$ & 6 & 46 \\
\hline $2-4$ & 2 & 15 \\
\hline$\geq 5$ & 5 & 38 \\
\hline \multicolumn{3}{|c|}{$\begin{array}{l}\text { *Presented in Median (IQR) } \\
\text { †Chronic diseases include: diabetes, chronic obstructive } \\
\text { pulmonary disease, cerebrovascular accident, cancer, rheumatoid } \\
\text { disease, renal impairment, liver disease, heart failure, psychiatric } \\
\text { disease and cognitive impairment. } \\
\text { flncluding the disease of the current episode that is used in this } \\
\text { study. }\end{array}$} \\
\hline
\end{tabular}

harm to the patients $(5 / 28=18 \%$; four were classified as level $\mathrm{E}$ and one as level $\mathrm{F}$ ).

\section{Cause}

The most common causes of TIs were human acts $(n=18)$ and organisation $(n=17)$. Examples of TIs caused by human acts can be incorrect or delayed diagnosis, incomplete (referral or discharge) letters and incorrect reassurance after only a part of the results of the diagnostics are known. An example of TIs caused by organisation is a structural problem within a department that results in delayed (discharge) letters.

\section{Preventability}

Seventeen out of 28 incidents $(61 \%)$ were considered as potentially preventable $(8 / 16$ of the unsafe situations, $4 / 7$ of the near misses and $5 / 5$ of the adverse events).

\section{Concordance between medical records and patient interviews}

Table 5 shows the concordance between the medical records and patient interviews. Of the total of 28 identified TIs, $20(71 \%)$ were clearly identifiable from the medical records. Three incidents (11\%) were only reported by patients, and were not identifiable in the medical records. Of another five reported incidents $(18 \%)$, clues were found in the medical records, but only after initial suggestion by the patient in the interview. Thus, these would have been missed without the initial alert by the patient. Six incidents were found only in the medical records and were not reported by patients. Thus, the concordance in TIs identified through patient interviews and those identified using medical records was $64 \%(18 / 28)$. TI's we probably could have missed when only using the medical records, comprise of the following: delay of referral or diagnosis, ambiguity of discharge procedures or responsible physician to the patient and incomplete medical records (either because of inadequate registration by the physician or incompleteness of received medical records). Incidents missed when only using the patient interviews comprised delayed information (eg, discharge or outpatient letter) and a dissimulating patient in the interview.

\section{DISCUSSION}

\section{Main findings}

In this pilot study of 78 transitions, 28 transitional safety incidents occurred. Twenty of these TIs could easily be identified from the records and five could be found in the medical record, but their identification was assisted by the information acquired from the patient interviews. Three TIs mentioned in the patient interviews were untraceable.

Concerning the characteristics of these TIs, 23 were classified as unsafe situation or near misses. Five TIs caused the patient temporary harm (adverse events). 
Table 3 Example of a patient journey with corresponding narrative of timeline and analysis of transitional incidents

\begin{tabular}{|c|c|c|}
\hline $\begin{array}{l}\text { Time from first } \\
\text { consultation }\end{array}$ & Narrative of timeline & $\begin{array}{l}\text { Transitional incidents } \\
\text { In this example, } 4 \text { separate transitional } \\
\text { incidents can be identified: }\end{array}$ \\
\hline 0 weeks & $\begin{array}{l}\text { A 73-year-old patient consulted the GP with epigastric pain } \\
\text { and was treated with omeprazole according to the current } \\
\text { guideline. }\end{array}$ & \\
\hline 2 weeks & $\begin{array}{l}\text { The patient returned to the GP's office with persistent } \\
\text { epigastric pain. The GP increased the dose and suggested to } \\
\text { wait and see. Routine laboratory tests showed no abnormal } \\
\text { results. }\end{array}$ & \\
\hline 4.5 months & $\begin{array}{l}\text { The epigastric pain continued and new symptoms surfaced: } \\
\text { loss of appetite and weight loss. The patient was seen by a } \\
\text { different GP. This GP suspected the presence of Helicobacter } \\
\text { pylori and suggested a stool antigen assay or endoscopic } \\
\text { testing. The patient chose the faecal assay. }\end{array}$ & \\
\hline 4 months and & The stool antigen assay was negative (possibly false & \\
\hline 3 weeks & $\begin{array}{l}\text { negative, because the GP did not instruct the patient to stop } \\
\text { the omeprazole temporarily). }\end{array}$ & \\
\hline $\begin{array}{l}5 \text { months and } \\
1 \text { week }\end{array}$ & $\begin{array}{l}\text { Again, the patient returned to the GP's office and was seen by } \\
\text { the first GP who referred her to the hospital for an endoscopy. }\end{array}$ & \\
\hline 6 months & $\begin{array}{l}\text { After a delay of } 4 \text { weeks, the patient received a letter from the } \\
\text { hospital about an appointment } 6 \text { weeks further on. The GP } \\
\text { called the hospital and arranged an appointment at the } \\
\text { outpatient quick diagnosis unit } 4 \text { days later. }\end{array}$ & $\begin{array}{l}\text { 1. Incorrect referral: the patient was referred } \\
\text { to the regular outpatient clinic instead of } \\
\text { the outpatient QDU (NM). The presence of } \\
\text { a QDU was not known to the GP. }\end{array}$ \\
\hline 7 months & $\begin{array}{l}\text { In the hospital, the patient is diagnosed with T3NOMO gastric } \\
\text { cardia carcinoma. The treatment consisted of perioperative } \\
\text { chemotherapy followed by a total gastrectomy } 4 \text { months after } \\
\text { the diagnosis. }\end{array}$ & \\
\hline 13 months & $\begin{array}{l}\text { After an extended hospital admission because of several } \\
\text { complications after surgery (such as anastomotic leakage and } \\
\text { glucose fluctuations), the patient was discharged. One day } \\
\text { after discharge, the first GP visited the patient at home, } \\
\text { prescribed medication and started glucose monitoring. At this } \\
\text { moment, it was unclear to the patient how to use the diabetes } \\
\text { medication. The discharge letter stated that the hospital } \\
\text { requested the GP to monitor the glucose after discharge } \\
\text { without further instructions. }\end{array}$ & $\begin{array}{l}\text { 2. Unclear discharge procedure for the } \\
\text { patient: after discharge, it was unclear to } \\
\text { the patient how to use the diabetes } \\
\text { medication (US). } \\
\text { 3. Inadequate and incomplete correspondence } \\
\text { between the hospital and the GP: both the } \\
\text { patient and the GP were not fully aware of } \\
\text { the diabetes medication, monitoring, } \\
\text { vitamin B12 injections and who the } \\
\text { responsible physician was for further } \\
\text { treatment (GP or hospital) (NM). }\end{array}$ \\
\hline $\begin{array}{l}14 \text { months and } \\
1 \text { week }\end{array}$ & $\begin{array}{l}\text { Coordination of the glucose monitoring and administration of } \\
\text { the medication continued to be unclear to the patient. The } \\
\text { patient and her family felt that the GP lacked control and } \\
\text { requested further glucose monitoring by an internist. The } \\
\text { patient was referred to the diabetes outpatient clinic in } \\
\text { hospital for follow-up. }\end{array}$ & \\
\hline 15 months & $\begin{array}{l}\text { When the patient visited the outpatient clinic, the surgeon } \\
\text { mentioned that vitamin } B_{12} \text { injections should have started } \\
\text { immediately after discharge. }\end{array}$ & $\begin{array}{l}\text { 4. Absence of an outpatient correspondence } \\
\text { to the GP and a note in the hospital } \\
\text { medical record about this specific } \\
\text { consultation. This resulted in a } 1 \text {-month } \\
\text { delay of administration of vitamin } \mathrm{B}_{12} \\
\text { injections (NM). }\end{array}$ \\
\hline 16 months & $\begin{array}{l}\text { At the next consultation, the surgeon asked the patient about } \\
\text { vitamin } B_{12} \text { injections. The patient was unaware that she had } \\
\text { to arrange this with her GP. She called the GP's office and } \\
\text { asked for the vitamin } B_{12} \text { injections. The GP did not know } \\
\text { about the injections because none of the letters mentioned } \\
\text { this advice. The GP checked the advice by calling the } \\
\text { outpatient clinic where it was found that the surgeon only } \\
\text { mentioned it. The surgeon had laid the responsibility for the } \\
\text { injections on the patient. }\end{array}$ & \\
\hline
\end{tabular}

AE, adverse event; GP, general practitioner; NM, near miss; QDU, quick diagnosis unit; US, unsafe situation. 


\begin{tabular}{|c|c|c|c|c|c|c|c|c|c|}
\hline Patient & $\begin{array}{l}\text { Age } \\
\text { (years) }\end{array}$ & $\begin{array}{l}\text { Gender } \\
M / F\end{array}$ & Narrative of patient journey & $\begin{array}{l}\text { Number of } \\
\text { transitions } \\
\text { (time span in } \\
\text { months) }\end{array}$ & $\begin{array}{l}\text { Number of } \\
\text { transitional } \\
\text { incidents }\end{array}$ & $\begin{array}{l}\text { Description of } \\
\text { transitional incidents }\end{array}$ & $\begin{array}{l}\text { Severity } \\
\text { (type: } \\
\text { NCC } \\
\text { MERP*) }\end{array}$ & $\begin{array}{l}\text { Preventability } \\
\text { (6-point scale) } \dagger\end{array}$ & $\begin{array}{l}\text { Estimated cause } \\
\text { of incident } \ddagger\end{array}$ \\
\hline \multirow[t]{4}{*}{1} & \multirow[t]{4}{*}{82} & \multirow[t]{4}{*}{$M$} & $\begin{array}{l}\text { A patient was admitted with heart } \\
\text { failure. After discharge, the }\end{array}$ & \multirow[t]{4}{*}{$\begin{array}{l}6 \text { (in } \\
3.5 \text { months) }\end{array}$} & \multirow[t]{4}{*}{$4 \S$} & $\begin{array}{l}\text { Incomplete and unclear } \\
\text { discharge procedure }\end{array}$ & $\begin{array}{l}\text { Near miss: } \\
\text { cat } C\end{array}$ & 4 & Human acts \\
\hline & & & $\begin{array}{l}\text { patient consults his GP, but the } \\
\text { GP had not received a discharge } \\
\text { letter. The delaved letter itself. }\end{array}$ & & & $\begin{array}{l}\text { Omission of removal of } \\
\text { peripheral IV catheter at } \\
\text { discharge }\end{array}$ & $\begin{array}{l}\text { Near miss: } \\
\text { cat } D\end{array}$ & 6 & Human acts \\
\hline & & & $\begin{array}{l}\text { once received, was unclear } \\
\text { about further monitoring of blood } \\
\text { values. Short hereafter, the } \\
\text { patient was readmitted. On } \\
\text { another occasion, the Peripheral }\end{array}$ & & & $\begin{array}{l}\text { Discharge letter: lacked } \\
\text { when patient consulted } \\
\text { GP (received } 2 \text { weeks } \\
\text { after discharge: not } \\
\text { delayed) }\end{array}$ & $\begin{array}{l}\text { Unsafe } \\
\text { situation: } \\
\text { cat A }\end{array}$ & 2 & $\begin{array}{l}\text { Organisation and } \\
\text { patient related }\end{array}$ \\
\hline & & & $\begin{array}{l}\text { IV catheter was not removed at } \\
\text { discharge from A\&E, so the GP's } \\
\text { assistant removed it. }\end{array}$ & & & $\begin{array}{l}\text { Delayed discharge letter: } \\
\text { lacked when patient } \\
\text { consulted GP (received } \\
4 \text { weeks after discharge) }\end{array}$ & $\begin{array}{l}\text { Unsafe } \\
\text { situation: } \\
\text { cat A }\end{array}$ & 4 & Organisation \\
\hline \multirow[t]{3}{*}{2} & \multirow[t]{3}{*}{42} & \multirow[t]{3}{*}{$\mathrm{F}$} & $\begin{array}{l}\text { A young patient was referred to } \\
\text { the outpatient QDU. She was } \\
\text { reassured several times by the } \\
\text { GP and in hospital during and } \\
\text { after rectal examination and }\end{array}$ & \multirow[t]{3}{*}{3 (in 6 months) } & \multirow[t]{3}{*}{3} & $\begin{array}{l}\text { Unprepared resident at } \\
\text { third appointment } \\
\text { (unaware of treatment), } \\
\text { resulting in temporary } \\
\text { mental harm }\end{array}$ & $\begin{array}{l}\text { Adverse } \\
\text { event: cat } \\
\text { E }\end{array}$ & 6 & Human acts \\
\hline & & & $\begin{array}{l}\text { colonoscopy, but diagnosis } \\
\text { turned out to be anal carcinoma. } \\
\text { The patient saw several doctors }\end{array}$ & & & $\begin{array}{l}\text { Inaccurate reassurance } \\
\text { by GP and after } \\
\text { colonoscopy }\end{array}$ & $\begin{array}{l}\text { Unsafe } \\
\text { situation: } \\
\text { cat } A\end{array}$ & 4 & Human acts \\
\hline & & & $\begin{array}{l}\text { at the QDU, resulting in faulty } \\
\text { and incomplete information } \\
\text { about the upcoming treatment. } \\
\text { The patient requested the GP for } \\
\text { a second opinion in another } \\
\text { hospital. }\end{array}$ & & & $\begin{array}{l}\text { Delayed outpatient letter } \\
\text { (delay: } 4 \text { weeks) }\end{array}$ & $\begin{array}{l}\text { Unsafe } \\
\text { situation: } \\
\text { cat } A\end{array}$ & 3 & Organisation \\
\hline \multirow[t]{3}{*}{3} & \multirow[t]{3}{*}{73} & \multirow[t]{3}{*}{$\mathrm{F}$} & $\begin{array}{l}\text { A patient was referred to the } \\
\text { hospital for a colonoscopy. When }\end{array}$ & \multirow[t]{3}{*}{6 (in 8 months) } & \multirow[t]{3}{*}{3} & Incorrect referral & $\begin{array}{l}\text { Near miss: } \\
\text { cat } D\end{array}$ & 4 & Organisation \\
\hline & & & $\begin{array}{l}\text { the patient did not get an } \\
\text { appointment for } 5 \text { weeks, the GP } \\
\text { contacted the hospital, which } \\
\text { informed the GP about the } \\
\text { existence of a QDU. The patient }\end{array}$ & & & $\begin{array}{l}\text { Unclear discharge } \\
\text { procedure regarding } \\
\text { diabetes medication and } \\
\text { glucose monitoring } \\
\text { (unclear to patient) }\end{array}$ & $\begin{array}{l}\text { Unsafe } \\
\text { situation: } \\
\text { cat A }\end{array}$ & 4 & Human acts \\
\hline & & & $\begin{array}{l}\text { was immediately referred and } \\
\text { diagnosed with gastric cancer. } \\
\text { The patient was operated and } \\
\text { developed diabetes mellitus. }\end{array}$ & & & $\begin{array}{l}\text { Unclear and incomplete } \\
\text { correspondence } \\
\text { between GP and } \\
\text { hospital }\end{array}$ & $\begin{array}{l}\text { Near miss: } \\
\text { cat C }\end{array}$ & 3 & Organisation \\
\hline
\end{tabular}




\begin{tabular}{|c|c|c|c|c|c|c|c|c|c|}
\hline Patient & $\begin{array}{l}\text { Age } \\
\text { (years) }\end{array}$ & $\begin{array}{l}\text { Gender } \\
\text { M/F }\end{array}$ & Narrative of patient journey & $\begin{array}{l}\text { Number of } \\
\text { transitions } \\
\text { (time span in } \\
\text { months) }\end{array}$ & $\begin{array}{l}\text { Number of } \\
\text { transitional } \\
\text { incidents }\end{array}$ & $\begin{array}{l}\text { Description of } \\
\text { transitional incidents }\end{array}$ & $\begin{array}{l}\text { Severity } \\
\text { (type: } \\
\text { NCC } \\
\text { MERP*) }\end{array}$ & $\begin{array}{l}\text { Preventability } \\
\text { (6-point scale) } \dagger\end{array}$ & $\begin{array}{l}\text { Estimated cause } \\
\text { of incident } ¥\end{array}$ \\
\hline & & & $\begin{array}{l}\text { After discharge, diabetes } \\
\text { medication and monitoring were } \\
\text { unclear to the patient and GP. } \\
\text { Prescription of vitamin } B_{12} \\
\text { injection was omitted and not } \\
\text { communicated to the GP. }\end{array}$ & & & $\begin{array}{l}\text { Absence of outpatient } \\
\text { letter and note in } \\
\text { hospital medical record } \\
\text { about consultation }\end{array}$ & $\begin{array}{l}\text { Near miss: } \\
\text { cat } C\end{array}$ & 6 & $\begin{array}{l}\text { Human acts and } \\
\text { organisation }\end{array}$ \\
\hline \multirow[t]{3}{*}{4} & 46 & $\mathrm{~F}$ & $\begin{array}{l}\text { A patient with dyspnoea was } \\
\text { discharged after a laparoscopic } \\
\text { hysterectomy and shortly after } \\
\text { readmitted with pneumonia. } \\
\text { Also, an unacknowledged }\end{array}$ & $\begin{array}{l}13 \text { (in } \\
10 \text { months) }\end{array}$ & 3 & $\begin{array}{l}\text { Patient was discharged } \\
\text { with breathing } \\
\text { discomfort (dyspnoea), } \\
2 \text { days later readmission } \\
\text { for pneumonia }\end{array}$ & $\begin{array}{l}\text { Adverse } \\
\text { event: cat } \\
\text { E }\end{array}$ & 4 & Human acts \\
\hline & & & $\begin{array}{l}\text { vesicovaginal fistula resulted in } \\
\text { persistent urinary incontinence, } \\
\text { for which the patient had multiple }\end{array}$ & & & $\begin{array}{l}\text { Delayed diagnosis of } \\
\text { fistula }\end{array}$ & $\begin{array}{l}\text { Adverse } \\
\text { event: cat } \\
\text { E }\end{array}$ & 4 & Human acts \\
\hline & & & $\begin{array}{l}\text { reoperations in another hospital. } \\
\text { This patient journey contains } \\
\text { transitions between GP and } \\
\text { physicians in } 2 \text { different divisions } \\
\text { of } 2 \text { different hospitals ( } 4 \\
\text { stakeholders in the hospitals). }\end{array}$ & & & $\begin{array}{l}\text { Incomplete discharge } \\
\text { letter: no mention of } \\
\text { postoperative bleeding } \\
\text { and urinary incontinence }\end{array}$ & $\begin{array}{l}\text { Unsafe } \\
\text { situation: } \\
\text { cat A }\end{array}$ & 6 & Human acts \\
\hline \multirow[t]{2}{*}{5} & 79 & M & $\begin{array}{l}\text { A patient underwent an } \\
\text { emergency operation because of } \\
\text { rupture of an AAA. Insufficient } \\
\text { guidance and information from }\end{array}$ & $\begin{array}{l}3 \text { (in } \\
3.5 \text { months) }\end{array}$ & 2 & $\begin{array}{l}\text { Delayed discharge letter: } \\
\text { lacked when patient } \\
\text { consulted GP (delay: } \\
4 \text { weeks) }\end{array}$ & $\begin{array}{l}\text { Unsafe } \\
\text { situation: } \\
\text { cat A }\end{array}$ & 6 & \\
\hline & & & $\begin{array}{l}\text { the hospital and the GP leads to } \\
\text { dissatisfaction in the patient. }\end{array}$ & & & $\begin{array}{l}\text { Unclear discharge } \\
\text { procedure }\end{array}$ & $\begin{array}{l}\text { Unsafe } \\
\text { situation: } \\
\text { cat } A\end{array}$ & 2 & $\begin{array}{l}\text { Organisation, } \\
\text { human acts and } \\
\text { patient related }\end{array}$ \\
\hline 6 & 70 & $\mathrm{~F}$ & $\begin{array}{l}\text { A patient was referred to the } \\
\text { outpatient QDU for a } \\
\text { colonoscopy. An incidental } \\
\text { gynaecological finding resulted in } \\
\text { an urgent referral to the } \\
\text { gynaecologist. }\end{array}$ & 2 (in 3 weeks) & 0 & None & NA & NA & NA \\
\hline 7 & 67 & M & $\begin{array}{l}\text { A patient was referred to hospital } \\
\text { for a colonoscopy but was } \\
\text { eligible for referral to the QDU } \\
\text { because of his previous history } \\
\text { of polyps. The GP was not aware } \\
\text { of the presence of a QDU. In }\end{array}$ & 2 (in 1.5 week) & 1 & $\begin{array}{l}\text { GP was unaware of } \\
\text { possibility to refer to } \\
\text { QDU, did not result in } \\
\text { delay of diagnosis }\end{array}$ & $\begin{array}{l}\text { Unsafe } \\
\text { situation: } \\
\text { cat A }\end{array}$ & 2 & $\begin{array}{l}\text { Organisation and } \\
\text { human acts }\end{array}$ \\
\hline
\end{tabular}




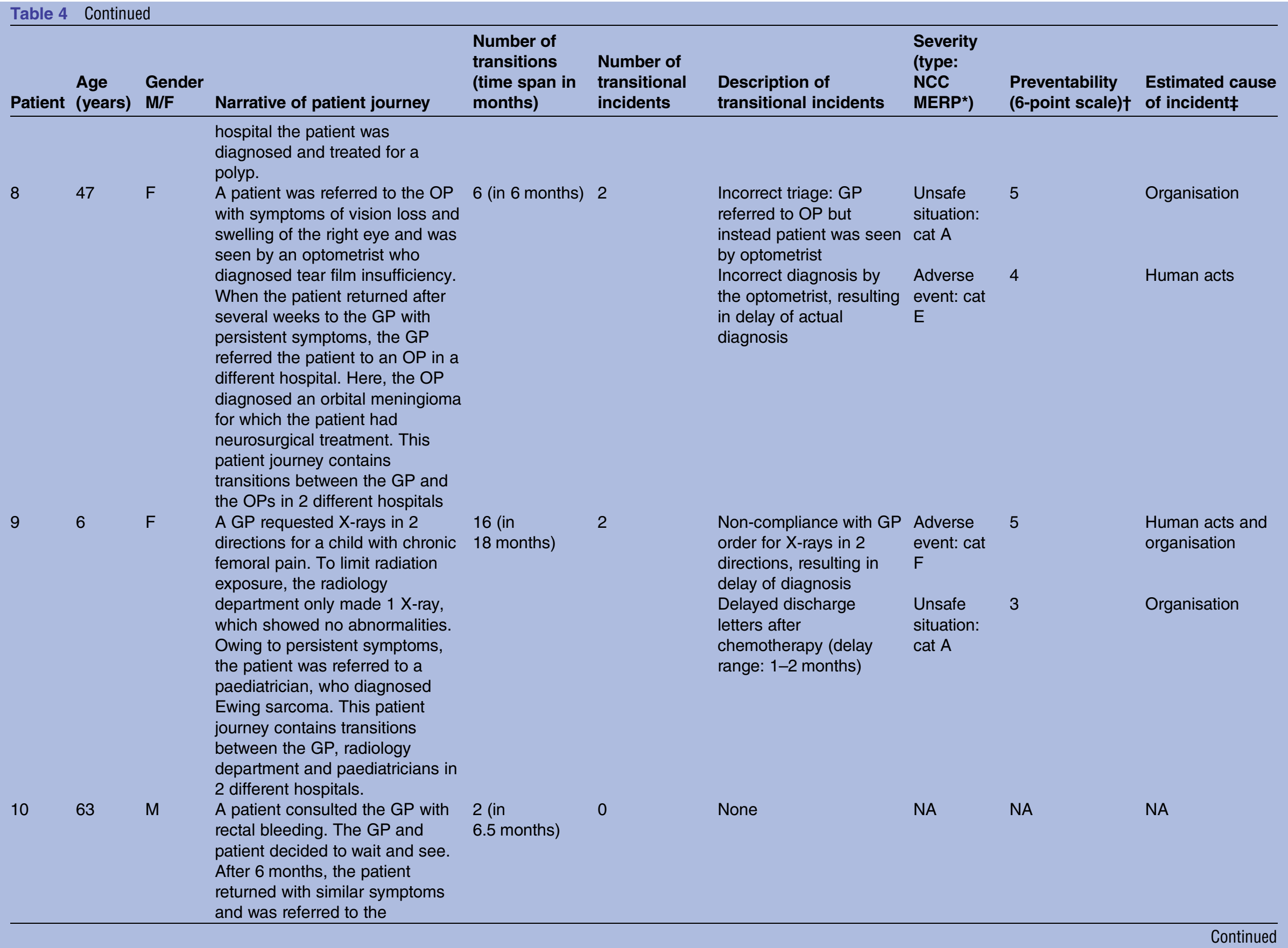

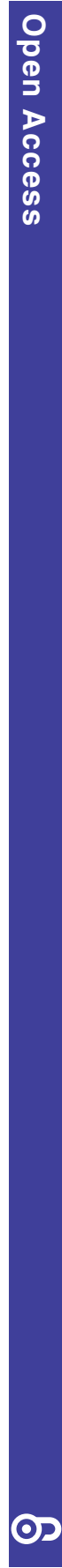


Number of

transitions Number of

(time span in transitional months) incidents

\section{Severity \\ (type:}

NCC
MERP*) transitional incidents

reventability Estimated cause (6-point scale)† of incident¥

outpatient QDU, where he we diagnosed with and treated for polyps.

$11 \quad 59 \quad \mathrm{M} \quad$ A patient contacted the GP

OHSC for sudden severe

headache and focal paraesthesia of the left arm. The GP OHSC suggested to wait and see. After persistent symptoms, the patient consulted his own GP and was referred to a neurologist who diagnosed a minor stroke. After discharge, the patient was not satisfied because of insufficien guidance and information from the neurologist, resulting in the patient consulting the GP.

$1250 \quad \mathrm{M} \quad$ A patient was referred to the rheumatologist and internally referred to a rehabilitation specialist because of osteoarthritis. Lyme disease was diagnosed (tested at the patient's request) and treated with antibiotics. The patient was not satisfied because of vagueness surrounding the Lyme diagnosis and lack of coordination of treatment, resulting in a second opinion.

The RS discovered an abnormal skin lesion and notified the GP. Excision of the skin lesion by the GP showed malignancy (excision and diagnosis is patient information only).

$13 \quad 36 \quad \mathrm{~F} \quad$ A patient was discharged and 11 (in readmitted because of persistent 12 months)

6 (in 7 months) 2

2 (in 2 months) 2
Delayed diagnosis of minor stroke

Insufficient guidance and lack of information from neurologist
Near miss: 2

cat D

Unsafe

situation:

cat $A$
Human acts

Human acts and organisation
Incomplete GP medical record: no mention of excised skin lesion

Unclear course regarding Lyme disease, situation: resulting in second opinion
Unsafe

situation:

Unsafe

cat $A$

$A$
5

2

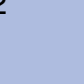

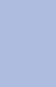




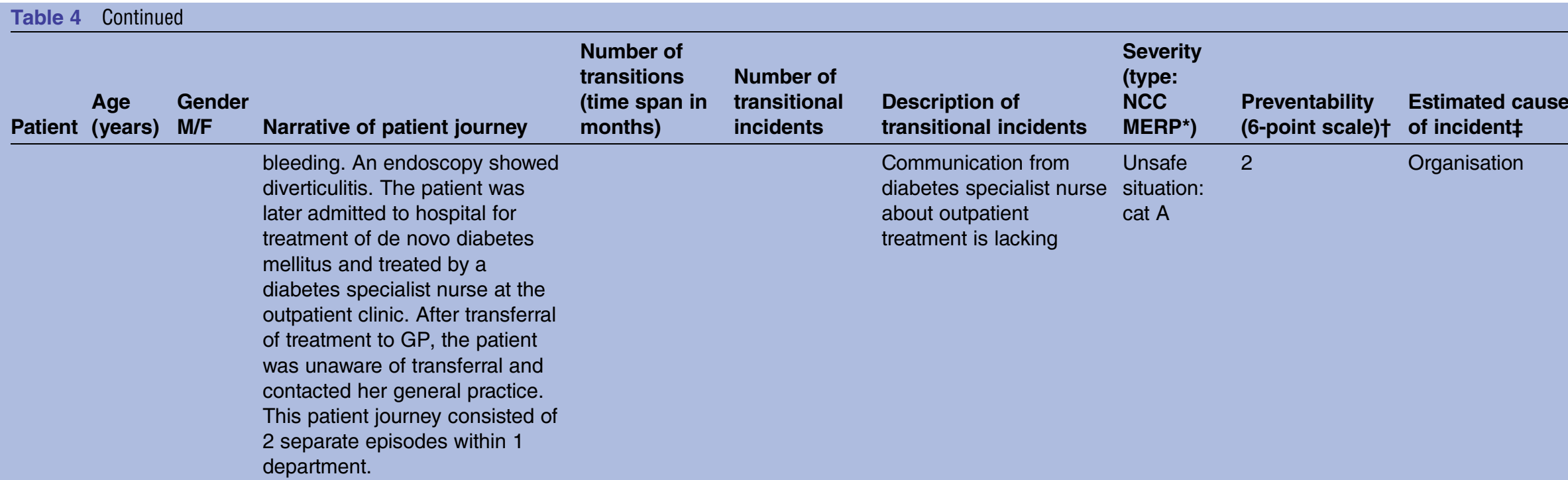

This table presents a short narrative of the patient journey and all identified transitional incidents and their classifications presented per patient.

*NCC MERP Index

A. 'Circumstances or events occurred that had the capacity to cause error',

B. 'Error occurred but did not reach the patient',

C. 'Error occurred that reached the patient but did not cause patient harm',

D. 'Error occurred that reached the patient and required monitoring to preclude harm or confirm that it caused no harm',

E. 'Error occurred that may have contributed to or resulted in temporary (mental or physical) harm or prolonged suffering from curable symptoms and required intervention',

F. 'Error occurred that may have contributed to or resulted in (mental or physical) harm and required an initial or prolonged hospital stay',

G. 'Error occurred that contributed to or resulted in permanent patient harm',

$\mathrm{H}$. 'Error occurred that required intervention to sustain patient's life',

I. 'Error occurred that may have contributed to or resulted in patient death'.

†Preventability score:

1. (Nearly) no evidence for preventability,

2. Slight evidence for preventability,

3. Possibly preventable but not very likely, $<50-50$ but close call,

4. Probably preventable, more than $50-50$ but close call,

5. Strong evidence for preventability,

6. (Definitely) evidence for preventability.

¥The assessment of causes was retrospectively carried out by two researchers (MAvM, CCAE) based solely on information from the patient interviews and medical

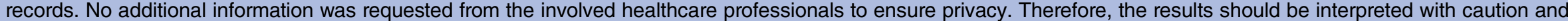
we decided to only identify the 'estimated' causes;

$\S$ Two out of four incidents cannot entirely be objectified. On the basis of the information from the medical records, the researchers cannot confirm whether the GP underestimated the patient's symptoms or if the situation fits the natural course of the disease.

A\&E, accident and emergency; AAA, abdominal aortic aneurysm; F, female; GP, general practitioner; IV, intravenous; M, male; NA, not applicable; NCC MERP, National

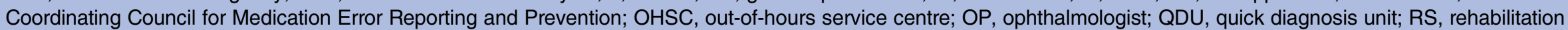
specialist. 
Table 5 Concordance between medical records and patient interviews

\begin{tabular}{llll}
\hline Data sources & \multicolumn{2}{l}{ Patient interviews } & \\
\cline { 2 - 3 } Medical records & Present & Absent & Total \\
\hline Present & 18 & 7 & $25^{*}$ \\
Absent & 3 & NA† & 3 \\
Total & 21 & 7 & 28 \\
\hline
\end{tabular}

This table reports in which data source the transitional incidents was present.

${ }^{*}$ In 5 of these 25 incidents, identification in the medical records proved challenging.

tThese incidents cannot be identified in both sources. This number is unknown.

NA, not applicable.

None of the identified TIs caused permanent patient harm, interventions to sustain patient's life or patient death. More than half of all of the incidents appeared to be potentially preventable.

\section{Strengths and limitations}

This study has several strengths. To the best of our knowledge, this is the first study in which patient interviews were compared with medical records to investigate transitional patient safety and the incidence of TIs. Record analysis proved superior: in the majority of cases, we found clues in the medical records that suggested the occurrence of a TI. The patient interviews did incidentally add TIs not found in the records.

Furthermore, this study encompasses the entire transitional care process as it includes all patient transitions between the GP and the hospital. Other studies have investigated patient safety and incidents, but these studies were limited to either primary ${ }^{11} 1920$ or secondary care. ${ }^{1021-23}$ We could have described the incidents in more detail; however, this was outside the scope and aim of this pilot study.

Our study also has potential limitations. First, to identify TIs, the researchers (MAvM, DCAE) depended mostly on information from the medical records, which was sometimes incomplete. For instance, the medical record did register an outpatient visit, but lacked a report on the content of the consultation. Also, referral or discharge letters were sometimes missing. The problem of incomplete medical records is inherent to medical record review studies and probably leads to an underassessment of incidents. ${ }^{24}$

When only relying on the medical records (our main intent of this pilot study), an incomplete medical record (either because of inadequate registration by the physician or incompleteness of received medical records) can lead to underestimation of all types of TIs because of insufficient information. Other incidents that could also be missed are based on wrong, unclear or lacking information given to the patient, for example, problems in the discharge procedure or assignment of a care coordinator. Information provided to the patient is often not registered in the medical record. Second, by starting analysis with the patient, interviews could have created hindsight bias as the researcher was not initially blinded when reading the medical records. Indeed, in five incidents, we found clues in the medical records, but these could have been missed without the guidance of the patient interview. This may have led to overestimating the concordance between patient interviews and the medical records. However, this approach helped identify subtle triggers in the transitional medical records, which will potentially improve the development of our future medical record review tool.

Third, the classification models used for classification of the TIs are not developed and validated for transitional care. For example, the NCG MERP Index for severity of harm has been developed for medication harm. However, since it was commonly used in medical record studies, ${ }^{10} 1125$ and its categories were reasonably applicable, we chose to apply this in our study. The same applies to the Eindhoven Classification Model for causes of incidents and the six-point scale for preventability ${ }^{26}$ In the classification of the causes of the identified TIs, it is plausible that there is an overestimation of the human causal component. This would be caused by the lack of background information that is usually collected in a formal incident analysis procedure. In the medical records, we are only able to judge the TI as a single independent incident. The organisational elements (eg, the availability of a protocol, training of healthcare professionals or patient safety culture) and technical causes (eg, badly functioning or imprecise devices) underlying incidents are usually not registered in the medical record. Other contributory factors, like information on time pressure and multitasking, were also not in the medical record. Since this is a pilot study, the methods of identifying TIs are still under development and TIs were identified jointly by two researchers.

Finally, the small sample size of our study and the purposive recruitment method do not permit generalisation of the results. Our study population consisted of patients with a higher risk of TIs because it served the purpose of our study, which was to test if TIs can be identified using the medical records of the GP and the hospital. In the general population, possibly less TIs occur. We have also probably missed the most serious TIs causing permanent harm or death because of our sampling method starting with the patient interview.

\section{Comparison to the literature}

Research has already shown that concordance exists between patient-reported incidents and other methods of incident detection (eg, medical record review studies, healthcare workers incident reporting, observation of consults). A systematic review by Ward and Armitage ${ }^{27}$ found that the highest concordance in hospitals lies between patient reporting and the medical record, ranging from $40 \%$ to $77 \%$ ). ${ }^{22} 28{ }^{29}$ In primary care, less research on this topic is conducted. Starfield et $a l^{\beta^{0}}$ 
showed a concordance ranging from $68 \%$ to $85 \%$ between medical records review and observation of consults between the GP and the patient. However, all of these studies have been conducted within one level of healthcare. This study showed a similar concordance between patient-reported incidents and medical records from the GP and the hospital in transitional care.

In healthcare transitions, however, record review studies face several challenges. Transitional safety incidents are usually not reported in routine incident reporting systems, and for adequate identification and analyses medical records are required from both healthcare settings, namely the GP and the hospital. These records differ in structure and design, which hampers their linkage. Subsequently, even if the patient records from the GP and the hospital are collected, incidents related to the transition in care will often be difficult to identify, as they are simply not registered.

Therefore, it is important to look for mismatches (eg, medical histories, dates of hospital visits and correspondence) or redundant information (eg, similar X-rays conducted by the GP and the hospital within a short period). Other clues include registered discontent of patient or healthcare provider (eg, large numbers of consults, requests for a second opinion, emotional comments of a healthcare provider on communication with another healthcare provider). Also, possible consequences of TIs can provide a clue for its occurrence (eg, death or readmission). For our main research study on transitional patient safety (TIPP),$^{13}$ we will further develop a method to link the electronic medical records of the GP and the hospital to identify and classify TIs within these data. Identification of these TIs will provide information to both the GP and the hospital for learning and improving patient safety in transitional care.

\section{CONCLUSION}

This pilot study suggests that the majority of TIs can be identified in medical records, although numbers were small. Although patient interviews facilitate the identification process, they may not be necessary. With this information, we aim to further develop and test a method to identify TIs in the medical records of the GP practice and the hospital, without the guidance of patient interviews.

Acknowledgements The authors would like to thank all of the participating patients for their stories and Ineke Mol for collecting part of the interviews. They also would like to thank Maaike Langelaan for her advice on the medical record review study.

Contributors MAvM and DLMZ initiated the study. MAvM, DCAE, HFvS, NJdW and DLMZ designed the study. MAvM and DCAE performed the study and developed the manuscript. DLMZ closely supervised the manuscript development. MAvM, DCAE, HFvS, NJdW and DLMZ participated in reviewing and editing various drafts of the manuscript and they all read and approved the final manuscript.

Funding This work was supported by the Dutch Ministry of Health, Welfare and Sports (VWS; grant number 320698), and Achmea Healthcare (grant number Z415).
Competing interests None declared.

Patient consent Obtained.

Ethics approval METC UMC UTrecht.

Provenance and peer review Not commissioned; externally peer reviewed.

Data sharing statement No additional data are available.

Open Access This is an Open Access article distributed in accordance with the Creative Commons Attribution Non Commercial (CC BY-NC 4.0) license, which permits others to distribute, remix, adapt, build upon this work noncommercially, and license their derivative works on different terms, provided the original work is properly cited and the use is non-commercial. See: http:// creativecommons.org/licenses/by-nc/4.0/

\section{REFERENCES}

1. Naylor M, Keating SA. Transitional care. Am J Nurs 2008;108(9 Suppl):58-63.

2. Coleman EA, Boult CE, on behalf of the American Geriatrics Society Healthcare Systems Committee. Improving the quality of transitional care for persons with complex care needs. J Am Geriatr Soc 2003;51:556-7.

3. Amalberti R, Benhamou D, Auroy $Y$, et al. Adverse events in medicine: Easy to count, complicated to understand, and complex to prevent. J Biomed Inform 2011;44:390-4.

4. Brennan TA, Leape LL, Laird NM, et al. Incidence of adverse events and negligence in hospitalized patients. Results of the Harvard Medical Practice Study I. N Engl J Med 1991;324:370-6.

5. Leape LL, Brennan TA, Laird N, et al. The nature of adverse events in hospitalized patients. Results of the Harvard Medical Practice Study II. N Engl J Med 1991;324:377-84.

6. Wilson RM, Runciman WB, Gibberd RW, et al. The quality in Australian Healthcare Study. Med J Aust 1995;163:458-71.

7. Vincent C, Neale G, Woloshynowych M. Adverse events in British hospitals: preliminary retrospective record review. BMJ 2001;322:517-19.

8. Baker GR, Norton PG, Flintoft V, et al. The Canadian Adverse Events Study: the incidence of adverse events among hospital patients in Canada. CMAJ 2004;170:1678-86.

9. de Bruijne MC, Zegers M, Hoonhout LHF, et al. Onbedoelde schade in Nederlandse ziekenhuizen: dossieronderzoek van ziekenhuisopnames in 2004. Amsterdam: Instituut voor Extramuraal Geneeskundig Onderzoek, 2007.

10. Baines RJ, Langelaan M, de Bruijne MC, et al. Changes in adverse event rates in hospitals over time: a longitudinal retrospective patient record review study. Qual Saf Healthc 2013;22:290-8.

11. Harmsen M, Giesen $P$, Martijn L, et al. Patiëntveiligheid in de Nederlandse eerstelijnszorg anno 2009. Nijmegen: IQ healthcare, 2009.

12. Waibel S, Henao D, Aller MB, et al. What do we know about patients' perceptions of continuity of care? A meta-synthesis of qualitative studies. Int J Qual Healthc 2012;24:39-48.

13. Van Melle MA, Zwart DLM, de Bont AA, et al. Improving transitional patient safety: research protocol of the transitional incident prevention programme (TIPP). Saf Health 2015;1:13.

14. Zwart DLM. Incident reporting in general practice [PhD thesis]. Chapter 7: incident reporting methods in general practice: a systematic review on the relationship between design, acceptability and yield. Utrecht, 2011.

15. Agency for Healthcare Research and Quality (AHRQ). The AHRQ Web M\&M Glossary page. http://www.webmm.ahrq.gov/glossary. aspx (28 Aug 2015).

16. Aspden P, Corrigan JM, Wolcott J, et al. Editors for the committee for data standards for patient safety, institute of medicine. Washington DC: The National Academic Press, 2004.

17. Van der Schaaf TW, Habraken MMP. PRISMA-medical. A brief description. Eindhoven, The Netherlands: University of Technology, August, 2005. http://www.who.int/patientsafety/taxonomy/PRISMA Medical.pdf (28 Aug 2015).

18. National Coordinating Council for Medication Error Reporting and Prevention (NCC MERP). Types of Medication Errors: NCC MERP Index for Categorizing Medication Errors. http://www. nccmerp.org/sites/default/files/indexBW2001-06-12.pdf (28 Aug 2015).

19. Gaal S, van Laarhoven $\mathrm{E}$, Wolters $\mathrm{R}$, et al. Patient safety in primary care has many aspects: an interview study in primary care doctors and nurses. J Eval Clin Pract 2010;16:639-43. 
20. Kuzel AJ, Woolf SH, Gilchrist VJ, et al. Patient reports of preventable problems and harms in primary healthcare. Ann Fam Med 2004;2:333-40.

21. Friedman SM, Provan D, Moore S, et al. Errors, near misses and adverse events in the emergency department: what can patients tell us? CJEM 2008;10:421-7.

22. Weingart SN, Pagovich O, Sands DZ, et al. What can hospitalized patients tell us about adverse events? Learning from patient-reported incidents. J Gen Intern Med 2005;20:830-6.

23. Christiaans-Dingelhoff I, Smits M, Zwaan L, et al. To what extent are adverse events found in patient records reported by patients and healthcare professionals via complaints, claims and incident reports? BMC Health Serv Res 2011;11:49.

24. Zegers M, de Bruijne MC, Spreeuwenberg P, et al. Quality of patient record keeping: an indicator of the quality of care? BMJ Qual Saf 2011;20:314-18.

25. Griffin FA, Resar RK. IHI Global Trigger Tool for Measuring Adverse Events (Second Edition). IHI Innovation Series white paper. Cambridge, MA: Institute for Healthcare Improvement, 2009.
26. World Health Organization Alliance for Patient Safety. The conceptual framework of an international patient safety event classification: executive summary. Geneva, Switzerland: World Health Organization, 2006. http://www.who.int/patientsafety/ taxonomy/icps_full_report.pdf (28 Aug 2015).

27. Ward JK, Armitage G. Can patients report patient safety incidents in a hospital setting? A systematic review. BMJ Qual Saf 2012;21:685-99.

28. Weissman JS, Schneider EC, Weingart SN, et al. Comparing patient reported hospital adverse events with medical record review: do patients know something that hospitals do not? Ann Intern Med 2008;149:100-8.

29. Kaboli PJ, Glasgow JM, Jaipul $\mathrm{CH}$, et al. Identifying medication misadventures: poor agreement among medical record, physician, nurse and patient reports. Pharmacotherapy 2010;30:529-38.

30. Starfield B, Steinwachs D, Morris I, et al. Concordance between medical records and observations regarding information on coordination of care. Med Care 1979;17:758-66. 